\title{
eLyra
}

REVISTA DA REDE INTERNACIONAL LYRACOMPOETICS

Marcos Siscar

\section{Traduções impenitentes:}

"Perte d'auréole", de Charles Baudelaire, por Marcos Siscar

\section{PERDA DE ORIGINAL}

"Não acredito! Você por aqui? Em um lugar tão mal frequentado! você, o poeta difícil! o bebedor de vodca com canudo! Eis que muito me espanta!

- Calma, querido! Você conhece o terror que tenho da rua de comércio. Agora pouco, atravessando apressado de um lado a outro, e como eu saltasse os pontos podres desse caos onde a credulidade mata tanto quanto a convicção, meu original, cansado de ser lido, escapou das mãos e foi cair na lama. Não quis tirá-lo do meio da porcaria. Achei que seria menos grave perder a autoridade do que perder a piada. Além disso, segundo as próprias leis do comércio, desgraça alheia faz sempre alguém feliz. Agora posso traduzir como bem quiser, sem técnica nem compromisso, errar no idioma e na poética, como todos fazem. E aqui estou, parecido com você, seu semelhante, seu irmão!

- Não valeria a pena colocar um anúncio, ou falar antes com um filólogo de plantão?

- De jeito nenhum! Estou gostando daqui. Você, e só você, me reconheceu. Aliás, a afetação da regra me entedia. E depois, veja bem, é divertido pensar que algum mal tradutor vai querer tirar o original da lama, com cara de sério, e limpá-lo na camisa. Confirmar um pedante, que alegria! e sobretudo um sisudo que me fará rir! Pense em $\mathrm{X}$ ou em Y! Que tal? Vai ser um furdúncio!" 